\title{
THE RELATION OF THE MIDDLE EAR PNEUMATISATION AND THE CATARRHAL OTITIS MEDIA
}

\author{
By \\ T. GOTO and T. KAIEDA

\begin{abstract}
From the Department of Oto-Rhino-Laryngology, Nagasaki University School of Medicine (Director: , Prof. T, Goto)
\end{abstract}

It has been rcognized that the acute otitis media occurs in the middle ear with well-developed pneumatisation, and chronic otitis media in that with the under-developed pneumatisation. Also some authors reported that the catarrhal otitis media was seen in the middle ear with the underdeveloped pneumatisation. It is the purpose of this paper to study the difference in the incidence of the chronic otitis media and catarrhal otitis in regard to the pneumatisation of the affected ears.

Authors studied the pneumatisation rentgenologically on 64 cases of catarrhal otitis in which the transudation had been confirmed in the tympanic cavity. In $50 \%$ of all cases moderate pneumatisation was revealed. In $20.3 \%$ underdeveloped and in $29.7 \%$ welldeveloped pneumatisation was seen.

In regards to the classification of the pneumatisation, authors divided all cases into 6 groups, according to the grade of extention of the cell figures on the $\mathrm{X}$-ray films and designated the middle two groups as the moderate pneumatisation.

\section{中耳カタルと Fneumatisation との関係に就いて}

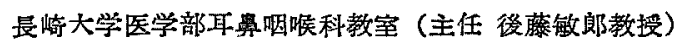 \\ 教授後藤繁 郎
}

\section{緒 啬}

中耳カタルは臨床上震々遭遇する疾患であり，中耳腔 のみならずこれれ連なる後方の中耳蜂笨内湴溜液 の存在がみられ，慢性にも経過して治澺し難い例があつ て原因も耳管の狭捾のみによるものとは考元難く，出 性中耳资と見做されるるのが多い。

中耳カルの成因に関しては，機械的原因説と炎疾的 原因説とが存在している．炎症説から見ると中耳カタル は鹰子鼻咽頭炎火綕発寸るのに，何故に急性化膿性中耳 炎にならないかと云5所に不審が存在しここに局所体 質的な影嚮に就いて考慮を払うべき余地が存在する。 又 機械的説からみると，患耳の中耳腔及心゙これに連なる中 耳䗋窼の発育度がいか程に関係しているか険討さるべき 問題で奠る。

中耳カタルとその中耳蜂漅に関するてレ」線学的な研 究火は，わが国沁いては，吉見1）片桐2)山田氏）等
の報告があるが，何れる中耳カタルは中耳蜂登発育度の 不良なるのに䍜患し易いとのみ発表されている，若しそ

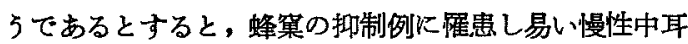
炎といかなる差異があるのか，又抗生物筫使用の普及に よつて蜂集の発育度との間にいかなる羑異が生じたるの か，中耳腔の疾患に和ける局所的条件を考光る上飞必要 な問題であると思5ので今回こつに調查を行つた。

\section{文献に就いて}

既行報告された中耳カタルととの中耳 Pn の発育度 に関する文献つ成績を図示すると第 1 表の如くである.

これ等つ観察はすべて臨床的に分泌夜の認められた中 耳カタルについてその非蜂巢の発育度を「レ」線学的 に測定し，これを良好，中等度，抑制の 3 種に分類した あのであつて，その分類の方法法蜂案の側面候における 広さの主観的判定によるものである。

1）吉見氏は 37 患耳について，Pn 発育良好型には全 
第 1 表 由可カタルと含気状態との関倸の (1)

离好
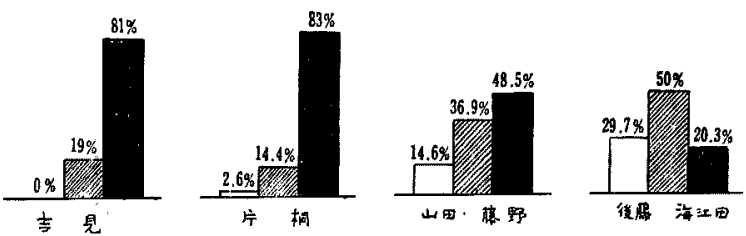

るむのを発育抑制 Pn gehemmt とする.更に良 好，抑制を夫ょその度に従つて各々 3 段階に分ち gut $(H),(H),(t)$, gehemmt $(t),(H)$, (州)の 6 段階にする. その境界にあるるのでは蜂 菓の大いさ，整不整を参烤にして良好 gut (+) か又は抑制 gehemmt（十）かの何れかに属せし むることにした。

なお、わが国に扗い、中耳カタルの「レ」線 像関する交献恃夫々その含気状態の分類法の基 準が異つているために著者等の成績との比較に困

く罹患をみず，中等度のわのに 7 例，即ち総㭘耳数の約 19\%が䍜患して招り，抑制型に 30 例（81\%）が䍜患し ていたと報告し、币耳カタルは中耳 Pn の抑制型のむ のに発病すると云つている.

II) 片桐上は 153 患耳飞ついて，良好型 4 耳 (2.6\%)， 中等照のもの 22 耳 $(14.4 \%)$ ，抑制型 127 耳 $(83 \%)$ な る成績を報告し，吉見氏と同様に本疾患は中耳 Pn の 抑制型に登育すると述べている。

III) 山田，藤野氏は 103 患耳について，良好型 15 耳 (14.6\%)，等度のもの38耳 (36.9\%), 抑制型 50 耳 (485\%) の成績が得られ, 前 2 者程ではないが矢張り抑 制型に罹患し易いと述へ，更に被検者総数 86 名利 69 名 の 1 側性患者について，先の健側と患側に和汗る中耳 Pnを比較し, 患側のPn は大多数は健側 Pnよりる 発育ぶ抑制されたものであつたと記載している。

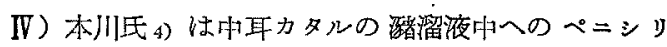
ンの移行とPn との関係を観察するために行つた観察 では13例の少数ではあつたがこれ等の中耳カタルの 「レ」線像何れむPn 発育度に良好 $(+) \sim(H)$ K属 するもの, 即ち発育度軽度良好のものが多いとしてや」 異つた成續を報している。

\section{研究方法}

研究材料としては鼓膜穿刺に上つて浸出液を認めた忚 耳カタル患者46名，64患耳几つきの側頭骨に打ける 中耳蜂窗の状態をSchüller 氏撮影法によつて撮影し， その影像を主として形態学的ふ量的な面てついて観察し た。

「凤耳の蜂窠含気状態の分類法に就いてはWittmaack， Schwartze, 義江, 山下，後藤の諸法’゙あるが，著者等 は患者の非 Pn の発青度の観祭を主とするために， 後藤法火よつた。後藤の分類注は，側頭骨の側面像に打 ける岩㨾骨三角を基淮として，蜂窂の発育がこの線を越 えている場合を発育良好 Pn gut とし，基準内に止ま
難を感じたので，他との比較のため gut (H)，(卅）を 良好型, gut $(+)$, gehemmt (十) を中等度型, gehemmt (H)，(卅) 抑制型とした.

\section{症例及び研究成績}

被検者総数 46 名, 92 耳のうちで币耳カタル患耳は 64 耳であつた．64患耳の5ちでの18名 36 耳け両側性で あり,一側性のむの 28 名 28 耳であつた。

第 2 表 叫咠カタルと含気化状熊との関际の

(2)

\begin{tabular}{|c|c|c|c|c|c|c|c|c|}
\hline \multirow{2}{*}{ 媌 查対 像 } & \multirow{2}{*}{ 人圓 } & \multirow{2}{*}{ 腎.耳数 } & \multicolumn{3}{|c|}{ 息 炬 型 } & \multicolumn{3}{|c|}{ 抑 制 型 } \\
\hline & & & $\mathrm{Ht}$ & $H$ & + & + & $H$ & H \\
\hline $\begin{array}{l}\text { 中耳 } \text { 耳タル } \\
\text { 患 橥 }\end{array}$ & 46 & 64 & 7 & 12 & 18 & 14 & 7 & 6 \\
\hline 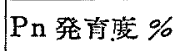 & & & 10.9 & 18.8 & 28.1 & 21.9 & 10.9 & 9.4. \\
\hline
\end{tabular}

これ等の「レ」線像に特ける Pn 発有度は第 2 表に

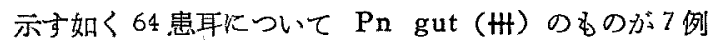
(10.9\%), gut (H) のもの12例 (18.8\%), gut (t) のもの 18 例 (28.1\%), gehemmt (+) のもの 14 例 (21.9\%), gehemmt (H)のむの7例 (10.9\%), ge. hemmt (H) のもの6例 (9.4\%) となり, gut (H), (H) を Pn 発育良好型, gut (+), gehemmt (+)を 中等度型, gehemmt (H)，(H) を抑制型とすると， 良好型儿属するものは19 例 $(29.7 \%)$ ，中等度型见属す るるの 32 耳 $(50 \%)$ ，抑制型得するるのは 17 耳 $(20.3$ \%)となつた。次に1側性䍜患者について健耳と患耳と の発育度を比較すると，健耳が患耳上り良好なるのは28 名中 11 例, 健耳側3゙不良なる 7 例, 両側3゙同煫なも の10例で西つた。

以上の如く著者等つ成績は一般の文献の報告之稍々異 なり，Pn 発育の归等度なるのが最も多く，本川氏の報 告と同様な成績を得，1側䍜患者飞扮いて子健側との比 較に見られる如く，健側の発育度の良好なるのに比較す ると発育度はや」悪いが，健側の発䏍度の抑制例に比較 
するとや〉良好である結果が得られた。

即ち、中耳 Pn の発背が 中等度のものが中耳カタル に罹患し易い一つの素因であることが明らか炕された。 この中等度と云う意味は上述のよ5に発育度が著しく悥 くむないが，又著しく良くもないと云う意味である。

交献の他の研究者の報告では抑帅型が多くなつている が，問題は抑制の程度であつて，著者のように分類する と gehemmt (十) は中等度のるの」らちに入れられて いる・若し報告者の例ぶ抑制型のうらでる軽度のものが 多いとなれば，結果恃著者のものと大差なくなる・又こ の抑制型を更に分類することは慢性中取炎沙強い抑制型 と認められることから必要なことでする。

\section{考按}

中耳カタルぶいかれ中耳の蜂笨の発筲不良なるのに䍜 患し易いかと云5問題について，Wittmaack は中耳 支び蜂柋粘膜の反応の特異性を重視し, 中耳の Pn の gehemmt なるのは，新生児及び哺乳肾特代の小耳炎に 起因した中耳及び蜂漅粘膜に組織的異常がありこのよ ラなものは軽い刺㦸によつて容易见炎症を起して分必液 を分必するか，又は，軽い陰化により Trausudat が出 睍するとるの説明した。

藤野氏は中耳蜂巢の発育が恶いと, その含気量が比 軽的少ないために耳管閉塞によつて, 陰圧がすみやか炕 発生し，これに Wittmack 氏の粘膜素因が加わつて本 症ぶ発症するものであるとしている。

徳田氏 6) の昭和 21 年より 25 年の 5 年間における中 耳カタルの出現率を統計的観察した成績では 23 年熦 より急泩中耳炎が激減し，これに反して中耳カタルが約 20\%増加している.その理由として急性中耳炎となるべ き症例が抗生物質の早期の使用により中耳カタルの像を 呈するに到ったものと思われるとしている. 又米国にお いても同時:期より中聶かタの増加が報告されたと附部 している.こ〉で中耳炎の経過と其の中耳のPn の発育 度との関係について考党てみる.中耳のPn の発育良好 なるの中耳炎が発病した場合, 強い症状が現われて急 性な経過をとり，反対に発育抑制例では症状弱く，慢性 経過をとることは既記䜑められている事聿である。

しかし，現在の抗生物質時代では急性中耳炎となるべ きもの>20\%が早期に，又は时耳炎を起可以前に括い て鼻咽頭かタルの㭙代に抗生物質のため以中耳カタルと なると考えられることから，Wittmaack 説が中耳カ タルの成因に最大の必要条件とは考えられない中耳の Pn gut のものに急性化膿性中耳炎が発病し, これに抗
生物質を投与した場合にあるるのはその秀〉性中耳炎 として経過するが，号るあのは中耳カタルとして経過す ることの考之られることは投生物質による起炎菌の死滅 による战莫の刺㦸の減弱, あるいは変化によるものと思 われる。この場合には㜀呫膜には主として細菌の異物 的刺戟のみが残ると思われる。このことから洘方ると， 中耳カタルを淩出性中耳炎としてみるとさには細菌感染 汶対する防算的反応であり，それがや耳の局所状態即ち 中等度のPn と染い関係があると推測される。

徳田氏仕耳管狭窄㭧者 1889 例他つき統計観祭を行い，

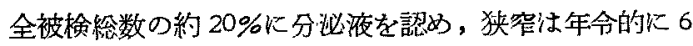
〜25 才に最む多くみられるが，その5ちで分必液の見 られるものは $17.9 \%$ にすぎないこれに刘して60才以 上に扔いては狭窄の出現は最も少いに拘わらず，元の $50 \%$ 大分必液が証明され，分泌夜の出現と年令との間に 何等かの関係があるのではないかと言つている，即ち耳 管の狭涳と分泌液との関係を年令別见比較観繁すると， 㹨窄は若年者に多く出現するにす拘わらす，分必夜を証 明するものは少なく，反対に年令の堌加々共儿狭䆣ゔ少 なくなり，初老期以後狭窄を認める者の約半数儿分泌夜 を証明している。

第 3 表 年合の闑倸

\begin{tabular}{|c|c|c|c|c|c|c|c|}
\hline 年 令 & $0 \sim 10$ & $11 \sim$ & $21 \sim$ & $1 \sim 40$ & $1 \sim 50$ & $51 \sim 60$ & $\begin{array}{l}61 \text { オ } \\
\text { 以上 }\end{array}$ \\
\hline 波稄数 & 2 & 2 & 7 & 5 & 9 & 10 & $1 \mathrm{i}$ \\
\hline 濩患数g & 4.35 & 4.35 & 15.2 & 10.9 & 19.6 & 21.7 & 239 \\
\hline
\end{tabular}

著者の観繁见特いても，第3 表に示す如く46名中0 10 才が 2 名 (4.35\%)，11〜20才が 2 名 $(4.35 \%), 21 〜$ 30 才が 7 名(15.2\%)，31〜40才が 5 名 (10.9\%)，41〜 50 才が9名(19.6\%)，.51〜60才が10名(21.7\%)，61 才以上が 11 名 $(23.9 \%)$ の結果が得ら机，分泌液が認 められるものは 50 才以上のるのが 21 名存在し, 高令者 程分泌液の出現が増加している．この年令的意義拿気 腔学説より考察すると,中耳蜂策に晾汁る反応の根本問 題はその周囲組織への骨吸収の強さ，含ち含気化せんと する Energie の強さである.その Energie の強さは 中耳の䗋菓周囲組織の粘膜下組織と骨組織との間に見ら れる骨の窝状吸収，粘膜下細胞浸潤等の強さに見られ る.この現象は新生児に最も強く，年令と共儿弱くなる が終生停止するものではない，高令者と云えども中耳の 蜂窠のどこか搪張部分がみられる。この根本的な年令 的な含気化力即ち発育力の强弱と分泌液の成因との間に 
何等かの䦭係があるのではなからうか、この含氛打は同

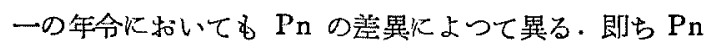
の良好なものほど発青力のよい聑であり，Pnの抑制 型程発青力のよくない中耳であり，それに良つて夫々の

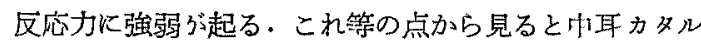

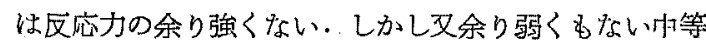
度の反応力を持つているものに起ると考えられる，年令 的の関係を反応力の上からみると, 高令者の多いこと は，年令的には粘膜の反応力は既に弱い侍期であるが， 含気状態の上からみるときは，多くは発育の最高度の状 態に達しているるのであるから，Pn は良好であり強い

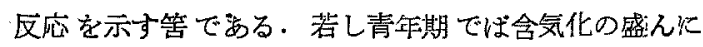
進んでいる時期であるから Pn は良好な例では更に强い 反応を示す筈である，しかし高令者では含気化機転その

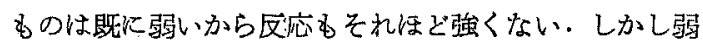
くむないと云う状態が考えられる。

耳管狭窄が中耳の分泌液の成因の一部に関係寸る事は 明らかであるぶ，斯る純䐑に器械的な原因によるるの> 他に，鼻咽頭カタルより続発した耳管啡耳タル Tu・ benmittelohrhatant では打耳蜂窠の状態即ち Pn が 梁い関係を持つていることが伺われる。そのPnの状態 は急性中耳炎引゙Pnの良好なるのに発現し，慢性小耳炎 がPn抑制的なるのに発現するに刘して，中耳カタルは 中等度のものに好んで発症することが確かかられた。鼾 咽頭炎に続発する中耳カタルの発症は恐らく細菌あるい はヴィルスの感染と関係があると思われるが，それ等の 起炎菌あるいは成因の問題は掖さにして中耳の局所的条 件が急性中耳炎中慢性中耳炎の場合と異つて, 中耳䗋窂 の方も余り強くも又弱くるない反店力を持つた粘膜であ ることが条件となつているようである。

\section{結 言}

中耳カタル46例 64 患耳に就て「レ」線的にその中耳 Pneumatisationを観察した。その結果中耳カタルは中 耳の Pneumatisation の中等度のbの即ち，余り良好
でもなく余り抑制的でるないるのに䍜患し易い，含気腔 学的にも粘膜反応の余り独くもなく, 余り弱くもない程

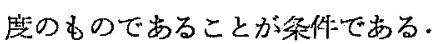

急性呵炎3 Pneumatisation 良好型な子のに見ら れ，慢性化脹性中耳炎3゙ Pneumatisation 抑莿型の女 のに認められることつよい対称をなしている。

\section{文 献}

1）吉見：「レ」線影像による乳嘴蜂窠発同度に関する 統計学的研究並びにその監底的湆義に就いて (II).十

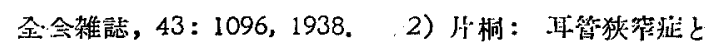

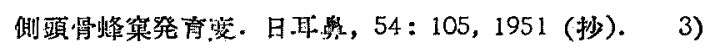
山田, 菊地, 藤野：分泌性山.耳:炎カタル（滲出性山.耳-

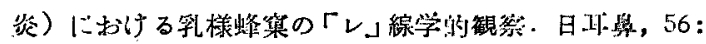
360, 1953. 4) 本川：中耳炎分泌中心の抗生物暂の 移行に影留する因子，特: Pneumatisation 2 の関保

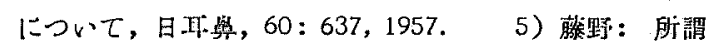

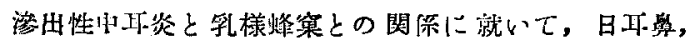
$52: 6,1949$ (抄). 6) 德田, 根本: 䎲管四四力タ几

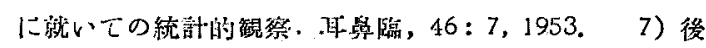

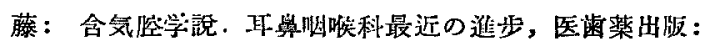

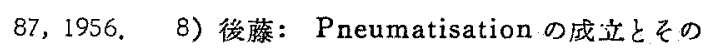

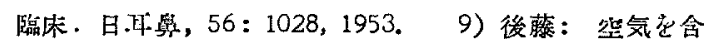

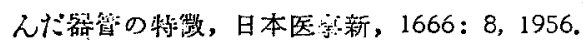

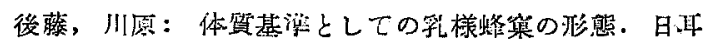

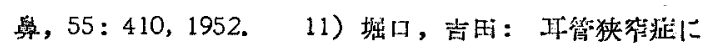

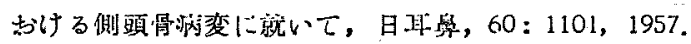
12) 重野：慢性的球炎々 Pneumatisation-hemmung

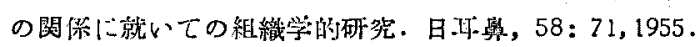

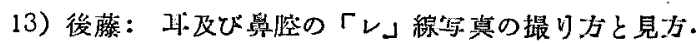

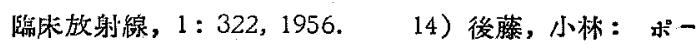

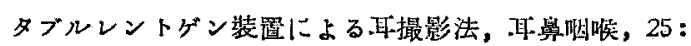
690, 1953.

（原搞到着=昭利 33.2 .13 日） 